\title{
A természetes termékenységi ráta gazdasági meghatározói, különös tekintettel az európai uniós és magyar viszonyokra
}

\section{The Economic Determinants of the Natural Fertility Rate with Special Regard to the EU and to Hungary}

\begin{abstract}
o.
Összefoglalás

A természetes termékenységi ráta közvetlenül kifejezi, hogy egy ország milyen reprodukciós képességekkel rendelkezik. A gazdasági értelemben fejlett világban jellemzóen sokkal alacsonyabb a mutató értéke, mint a kevésbé fejlett országokban. Azonban a fejlett országok köre sem teljesen homogén a termékenységi ráta tekintetében. Jelen tanulmány az európai uniós tagállamok mintáján vizsgálja, milyen gazdasági, gazdaságpolitikai tényezók eredményezhetnek javulást a termékenységi rátában. Fontos annak a bemutatása is, hogy globálisan milyen kapcsolatot lehet felfedezni a termékenységi ráta és az életszínvonal között. Lényeges megállapítása az írásnak, hogy a gyermekvállalás alapvetően nem gazdasági, sokkal inkább kulturális kérdés, és a felelôsségvállalással áll összefüggésben, mindezen túl önmagában a gazdasági stabilitás vagy a jövedelemeloszlás kiegyensúlyozottsága már okozhatja gazdasági paraméterként a termékenységi ráta növekedését. A tanulmány utal egyéb olyan változókra is, amelyek pozitív irányba mozdíthatják el a fejlettnek nevezett világban a negatív demográfiai trendeket.
\end{abstract}

Dr. Pintér Tibor PhD, adjunktus, Budapesti Gazdasági Egyetem, KVIK, Közgazdasági és Üzleti Tudományok Tanszék (Pinter.Tibor@uni-bge.hu). 
Journal of Economic Literature (JEL) kódok: J10, J13, F63, I15

Kulcsszavak: termékenységi ráta, gazdasági fejlôdés, szociális támogatások, elöregedés, jövedelemnövekedés

\section{Summary}

The natural fertility rate directly expresses a country's ability to reproduce. In those parts of the world that are considered developed in an economic sense, this ratio is significantly lower than in less developed countries. However, developed countries are not completely homogenous in respect of fertility rates. In this paper the economic and economic policy factors that may improve the fertility rate are analysed on the sample of European Union Member States. It is also important to present the correlation between the fertility rate and living standards. Having children is fundamentally not an economic but more a cultural matter, related to taking responsibility. In addition, economic stability or balanced income distribution are economic parameters that may nevertheless trigger increase in the fertility rate. Reference is also made to other variables that may have a positive impact on the currently negative trends in the part of the world called developed.

Journal of Economic Literature (JEL) codes: J10, J13, F63, I15

Keywords: fertility rate, economic development, welfare aids, ageing, income increase

\section{BeVEZETÉS}

Jelen tanulmányban a termékenységi rátát meghatározó gazdasági determinánsok beazonosítását céloztam meg. Köztudomású, hogy általában épp a komoly gazdasági erôforrásokkal rendelkezô országok esetében jelent komoly problémát a nem elegendó gyermekszám. Napjaink magyar közéleti vitáiban is hangsúlyt fektetnek a gyermekvállalás és a családtámogatás kérdésére. Ezt egyfelól rendkívül pozitív fejleménynek tekinthetjük, hiszen tudatosodott a politikai vezetésben is, hogy ez a jelenség egyre nagyobb kihívást jelent a fejlett világban. Azt viszont tovább fejlesztendô területként javasolhatjuk, hogy ne csak a gazdasági, pénzügyi oldalát próbálják megteremteni, támogatni a családalapításnak, hanem az érzelmi, individuális, nevelési oldalára is még nagyobb hangsúlyt lehetne fektetni. A kutatások, az adatsorok, valamint a mindennapi tapasztalatok arra engednek következtetni, hogy a családalapítás mögött egyfajta pozitív érzelmi, valamint világnézeti motivációs pillér azonosítható be.

Egy bevezetố erôsségének tudható be, ha meghökkentô, az olvasó figyelmét felkeltô tényeket közöl, vagy ilyen jellegú kutatásokra utal. A mostani tanulmány elején mindössze két adatkapcsolatra mutatnék rá, amelyek önmagukban azt bizonyítják, hogy nem pénzügyi befolyásoló eszközök fogják megoldani a termékenységi ráta válságát globális értelemben. Az egyik, hogy 2016-os adatok szerint egy átlagos magyar ember életszínvonala a Világbank adatbázisa alapján olyan magas, hogy a világ 
Pintér Tibor: A természetes termékenységi ráta gazdasági meghatározói...

népességének majdnem 85 százaléka az alatt él. Mégis jóval világátlag és a természetes reprodukciót biztosító érték alatti a hazai termékenységi ráta, több mint egy egésszel.

A másik ilyen adat pedig az idôbeli tendenciákkal van összefüggésben. 1960-ban még majdnem 5 volt egy átlagos földlakó termékenységi rátája, amelyhez hozzávetólegesen 450 amerikai dolláros egy fớre jutó átlagos GDP társult. 2016-ban (56 év után) ez az adatpár a következô: 2,44-es termékenységi ráta és 10200 dolláros egy fớre jutó átlagos GDP. Önmagában nem az 5-ös termékenységi ráta a kívánatos, de az irány több mint elgondolkodtató.

A tanulmány egészének üzenete azonban nem egészen ezt a negatív képet festi elénk. Amennyiben egy gazdasági értelemben igen fejlett országcsoportot, jelesül az Európai Unió 28 tagállamát vesszük górcsố alá, akkor már árnyaltabb képet tárhatunk az olvasó elé.

\section{Elméleti ÁtTEKINTÉS ÉS KUTATÁSI KéRdéSEK FELVETÉSE}

A közgazdaságtan a korai szakaszában sokkal természetesebben foglalkozott minden olyan kérdéssel és területtel, amelyekre a gazdasági folyamatok hatással vannak. Ilyen területnek tarthatjuk azt is, hogy olyan gazdasági rendszer múködtetése valósuljon meg, amely rendszer képes az emberhez méltó családi élet anyagi igényeinek megteremtésére. Napjaink gazdasági rendszerére igaz, hogy rendkívüli gazdagságot hozott létre, az azonban árnyoldala, hogy egyáltalán nem támogatja a családi életvitelt. Ilyen módon a jelenlegi gazdasági rendszer kudarcot vallott. Ez a kudarc természetesen nem elôzmény nélküli.

A széles horizonttal rendelkezó, korai közgazdasági elméletek után az úgynevezett klasszikus angol közgazdasági iskola (kezdeti vezéralakja Adam Smith) szisztematikusan rendszerezte e tudomány fogalmi és módszertani apparátusát az utókor közgazdászainak álláspontja szerint (Mueller, 2010). Ez a fejlemény azonban elszigetelte, specializációra sarkallta a tudományterület képviselôit. Innentôl kezdve már csak bizonyos szakterületeken tevékenykedô elméleti közgazdászok foglalkoztak és foglalkoznak például a gazdasági rendszer népesedési vetületeivel, demográfiai értelemben vett fenntarthatóságával. Ki kell emelni Thomas Robert Malthus munkásságát, aki eredetileg 1798-ban kiadott munkájában felvetette azt, hogy össze kellene hasonlítani a népesedés növekedési ütemének és a gazdaság teljesítóképességének potenciálját. Azon következtetése természetesen nem volt helytálló, hogy globális szinten a népesség növekedése permanensen magasabb ütemú lenne, mint a gazdaságé. Ettôl a ténytôl függetlenül azonban rá kell mutatnunk, hogy a világnak nem azokban a részeiben jellemzố az erôteljes népességnövekedés, ahol azt a gazdasági teljesítmény és életszínvonal indokolná. Minél hosszabb idôsorral rendelkezünk, annál erôteljesebb ellentmondásokat fedezhetünk fel e vizsgálódási területen.

Amennyiben bármilyen szaktudomány által fontosnak tartott változó és a népesedés, demográfiai pálya közötti kapcsolatot kutatjuk, önmagában felmerülhet az a kérdés is, hogy megfelelố mutató-e a termékenységi arányszám a függó változó sze- 
repére? A szakirodalmi áttekintés rámutatott arra, hogy a legtöbb esetben ez a mutató felhasználható függố változóként a modellekben (Becker, 1960; Berde-Németh, 2016).

Fontos kérdésfelvetés az is, hogy mutatkozik-e valamilyen irány a gazdasági fejlettségi szint és a termékenységi ráta között? Ismeretes, hogy a közgazdasági elemzésekben rendkívül sok kritikát fogalmaztak meg a GDP-vel és az SNA-mutatókkal szemben, mégis a legtöbb esetben a GDP-vel vagy abból származtatott mutatóval vetik össze a demográfiai trendeket (Berde-Kuncz, 2017). Gazdaságtörténeti aspektusban kifejezetten negatív kapcsolat áll fenn a jövedelmi szint és a termékenység között, ennek a magyarázatára külön termékenységi elméletek is születtek, amelyek kielégítô választ nem tudtak nyújtani a témában (Jones et al., 2010).

A másik fontos gazdaságtörténeti ihletettségú irányzata a termékenység gazdasági elemzésének az, hogy megpróbálnak rámutatni, mely gazdasági fejlettségi szinten törik meg a termékenység dinamikája, és milyen módon kapcsolódik a demográfiai pálya a gazdasági átmenetek sorához. A magas fejlettségi szinten levô régiókban (Prskawetz-Lindh, 2007), a közepes jövedelmi szinten levő, elszigetelt térségekben (Mason et al., 2008), valamint az alacsony fejlettségi szinten lévő, nagyobb országokban (Hussain et al., 2009) is felmerül a gazdasági átmenet és a termékenységi arányszám közötti kapcsolat feltérképezésének igénye. E kérdés szempontjából a világ legfejlettebb régióira ellentmondásos hatást gyakorolt a legutóbbi komoly világgazdasági válság is (Sobotka et al., 2011).

A globális értelemben fejlettnek tekinthetô, kiterjedt szociális ellátórendszerekkel rendelkezô, valamint múködó társadalombiztosítási rendszert is fenntartó országok (Sági et al., 2018) esetében válik igazán fontossá a demográfiai pálya és a gazdasági teljesítmény, valamint életszínvonal közötti kapcsolat értékelése (Berde-Kovács, 2016). Ennek az az oka, hogy jellemzően jóval alacsonyabb a gyermekvállalási hajlandóság a világnak ezen régióiban. Mindez kiegészül azzal a jelenséggel is, hogy ebben a jövedelmi tartományban már nem kifejezetten erôsen negatív a kapcsolat a két jelenség között, hanem egy gyenge pozitív összefüggés áll csak fent. Mindenesetre azt megállapíthatjuk, hogy egyfajta alternatív értékrend épül fel a fejlettebbnek nevezett társadalmakban a gyermekvállalást illetôen (Schultz, 1974).

A fiskális politika és az aktív állami szerepvállalás beavatkozási irányai, lehetôségei is komoly kutatási kérdésként merülnek fel ebben a kontextusban (Yang, 2016). Bár vannak különbségek a nyugdíjbiztosítási rendszerek között, mégis ki kell jelentenünk, hogy a kívánatosnál alacsonyabb gyermekszám, valamint az ennek kísérôjelenségeként felmerüló elöregedés olyan aggasztó irányokként jelentkeznek, amelyeket a jövôben kezelni kell (Széll, 2010). Az akadémiai és a politikai szférában egyaránt foglalkozni kell a kivitelezési lehetôségekkel.

Felmerülhet a gyermekvállalás, családalapítás és a társadalombiztosítási rendszer közötti közvetlen anyagi kapcsolat kiépítése (Giday-Szegő, 2018). Egy ország lakosságának várható élettartamára egyértelmúen pozitív hatást gyakorol a gazdasági növekedés, ez azonban nem jelenti egyben a családvállaláshoz szükséges egészséges állapot javulását is (Barro, 2013). Ilyen módon a késôbbiekben hasznos lehet az egészség és 
Pintér Tibor: A természetes termékenységi ráta gazdasági meghatározói...

gazdasági teljesítmény közötti kapcsolatok, valamint bizonyos civilizációs betegségek és a gazdasági teljesítmény közötti kapcsolatok feltárása.

Speciális kérdésként (például szociológiai, regionális gazdasági vizsgálatok keretében) fontos lehet a termékenység területi összefüggéseinek feltárása is (Varga, 2005). Egy adott országon, területi entitáson belül a prosperáló területek irányába sokszor pontosan a fiatalabb, családalapításra is vállalkozó népesség áramlik el (Sági-Lentner, 2018). Mindez azonban nem jelenti azt, hogy a korábban tervezett gyermekszámot el is érik, pontosan az újonnan felvett attitúdök miatt. Létjogosultsága van a vizsgálatoknak a hasonló fejlôdéstörténeti örökséggel és hasonló nemzetközi munkamegosztási szereppel rendelkezô országok esetében is. Farkas (2017) pontosan ezen okból kifolyólag veti össze Lengyelország, Csehország és Szlovákia családtámogatási rendszereinek múködését, és von le ebból következtetéseket a magyar rendszerre vonatkoztatva is.

Ugyancsak kiemelendô a nôk munkaerôpiaci szerepvállalása, képzettsége és a termékenységi ráta közötti ellentmondásos kapcsolat megléte (Yang, 2000). E szerint globálisan egyértelmúen negatív kapcsolat áll fenn a nôk aktívabb munkaerôpiaci részvétele és a termékenység között, a fejlettnek nevezett világban azonban nem ilyen egyértelmú ez a viszony. A természetes reprodukciós szint alatti tartományban már kimutatható pozitív összefüggés is az aktív nôi munkaerôpiaci részvétel és a gyermekvállalási hajlandóság között. Az olyan speciális elméleti közgazdaságtani kategóriák, változók, mint a munkanélküliségi ráta, a munkanélküliség jelensége, valamint annak társadalmi következményeként a gyermekvállalási attitúd pszichés alapja, szintén kapcsolatot mutathat egymással (Kucséber, 2011). Érezheti tehát úgy egy fejlettebb országban élő ember, hogy önmagában a munkahely elvesztése okot ad a gyermekvállalás elhalasztására. Ez azonban az adatbázisok alapján inkább egy szociológiai és pszichológiai érzet lesz számára, hiszen a magasabb életszínvonal egyértelmúen visszaveti a termékenységi rátát globális értelemben.

A tanulmányban törekszem arra, hogy a lehetô legnagyobb mértékben csak az adatok közötti kapcsolatokra mutassak rá. Ehhez természetesen az empirikus módszerek legfontosabb fajtáinak ismerete is szükséges. A kutatókat támogató magyar szakirodalom is jelentôs fejlôdésen ment át az utóbbi években. Az alaptáblák összeállításában és az elemzések futtatásában elsôdlegesen Molnár (2015) munkájára építettem. Ezt azonban kimagasló színvonallal egészítette ki Dusek és Kotosz 2016-ban publikált könyve, fôleg az apróbb, kimunkált értelmezési és adatgyújtési fogások tekintetében (Dusek-Kotosz, 2016).

Az elméleti áttekintést követôen megfogalmazom a tanulmányban elemezni kívánt legfontosabb kérdéseket. A világ egészére vonatkoztatva érdemes áttekinteni, hogy milyen nagyságrendi különbségek vannak egyes nagyrégiók gazdasági fejlettségi szintje és termékenységi rátája tekintetében. Mindezt nem kizárólag a jelenre koncentráló, keresztmetszeti, statikus képet adva érdemes megtenni, hanem a termékenység és a gazdasági fejlôdés idôbeli elmozdulásait is érdemes befoglalni a képbe. Ezt követôen azonban már csak az EU-tagállamokra fogok koncentrálni, hiszen ezekben az országokban a statisztikai rendszerek megbízhatósága magasabb fokúnak minôsülhet, vala- 
mint ezek az országok hasonló társadalmi-gazdasági helyzetben vannak, mint például Magyarország. Ezen országok körében közvetlen gazdasági változók, valamint szociológiai, regionális gazdasági változók bevonásával fogom beazonosítani a termékenység legfontosabb gazdasági meghatározóit. Leginkább regressziós modellelemzéssel és korrelációs mátrixok segítségével mutatok rá a domináns irányokra, kapcsolatokra.

 KÖZÖTTI KAPGSOLAT GLOBÁLIS KITEKINTÉSBEN}

Fontos bemutatni a kapcsolatot a gazdasági értelemben vett életszínvonal és a termékenységi ráta között. A gazdasági életszínvonal mérésére az egy fớre esố GDP-t használtam, annak ismert gyengeségei ellenére is. Az 1. ábra a világ összes országának GDP/fố és termékenységi ráta adatát mutatja. Nem egyezik meg a minta elemszáma az összes országéval, annál kevesebb. Ennek oka, hogy csak azokat a megfigyelési egységeket emeltem be a modellbe, amelyeknél mindkét adat rendelkezésre állt már a 2016-os évre vonatkozóan. Az ábra egy negatív összefüggésre mutat rá az egy fốre jutó GDP és a termékenységi ráta között. Ez a kapcsolat nem lineáris, sokkal inkább hatványos alakot ölt.

1. ábra: A termékenységi ráta és az egy före jutó GDP közötti kapcsolat a világ országaiban (2016)

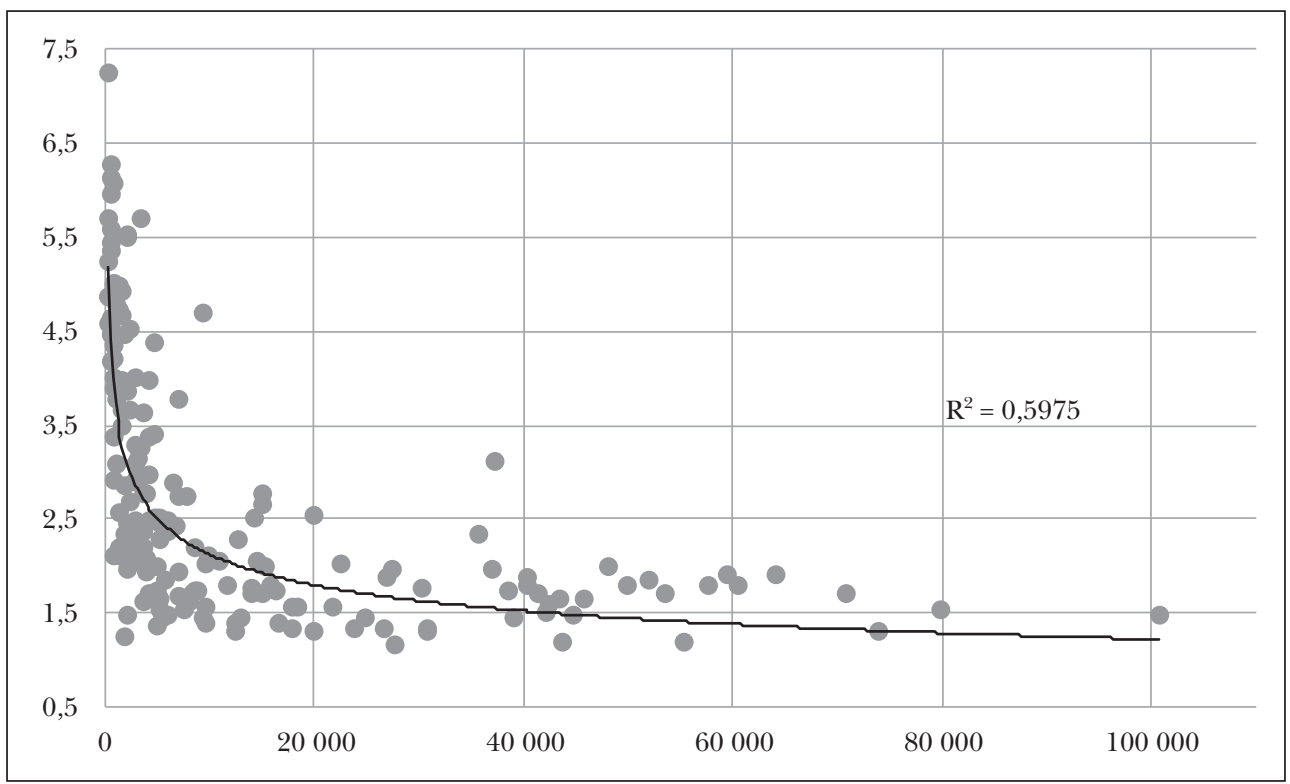

Forrás: Saját számítás a Világbank adatbázisa alapján

Az 1. ábra egyazon naptári évben, 2016-ban mutat statikus, keresztmetszeti összefüggést a két adat között. Az ábrán látható korrelációs koefficiens azt mutatja, hogy a feltételezett logaritmikus modellre milyen pontossággal illeszkedik a valódi adatokat 
Pintér Tibor: A természetes termékenységi ráta gazdasági meghatározói...

mutató pontfelhô. Az SPSS-programon lefuttatott pótlólagos modellszámítások szerint mind a logaritmikus regressziós modell, mind a korrelációs modell eredménye szignifikánsnak mondható. A Pearson-féle korrelációs mutató értéke -0,488, ami egy negatív, de nem kifejezetten erôs kapcsolatra utal az egy fốre jutó GDP és a termékenységi ráta között. Fontos megjegyezni az ábra értelmezése kapcsán, hogy az egy fơre jutó GDP (a vízszintes tengelyen szerepel, hiszen arra voltam kíváncsi, hogy menynyiben határozza meg az életszínvonal a termékenységet, ez utóbbi tehát mennyiben függ tôle) tekintetében különbözô elhelyezkedés jellemzô a pontokra. Jól kivehetô, hogy a szegényebb országok esetében igen gyakori a 3-as vagy annál jelentôsen magasabb érték a termékenységi rátára vonatkozóan, míg a gazdagabb országok esetében elvétve találunk 2-nél, 2,5-nél magasabb rátát, zömében 2 alatti számok a jellemzóek.

2016-ban Niger termékenységi rátája volt a legmagasabb, 7,24-os értékkel (amenynyiben két tizedesjegyre kerekítünk), ezt a nyugat-afrikai országot követte két másik afrikai ország, Szomália, valamint a Kongói Demokratikus Köztársaság, jóval 6 feletti értékekkel. A legalacsonyabb mért értékkel Dél-Korea rendelkezett a világon 2016-ban, ez 1,17 volt, mellette Szingapúr és Hongkong túnik még fel 1,2 körüli, nagyon alacsony mutatóval. 20000 dollár/fő feletti GDP-adat mellett mindössze Guam és Izrael került be a 2-es termékenységi ráta feletti csoportba, utóbbi 3-as érték felett. Ez a kiegészítés jól szemlélteti a mutatóknál erôteljesebb negatív kapcsolatot, ráadásul az össznépesség is inkább az alsóbb jövedelmi kategóriákba tartozó országokban összpontosul, vagyis a nagy népességszámú országok ebben a jövedelmi csoportban találhatóak.

Az egy adott idópontban vizsgálódó modell mellett egy idósoros elemzést is fontosnak tartottam elvégezni. Ebben a második modellben a világ átlagos lakosára számított termékenységi ráta és az egy fóre esố GDP közötti kapcsolatot elemeztem. A 2. ábra kifejezi, hogy az 1960 és 2016 közötti idôszakban, évenként milyen párokat alkotott a két mutató. Jól láthatóan erôteljesebb a negatív kapcsolat a két változó mozgása között.

2. ábra: A termékenységi ráta és az egy fốre jutó GDP közötti kapcsolat az egy lakosra jutó átlagos értékek alapján (1960-2016)

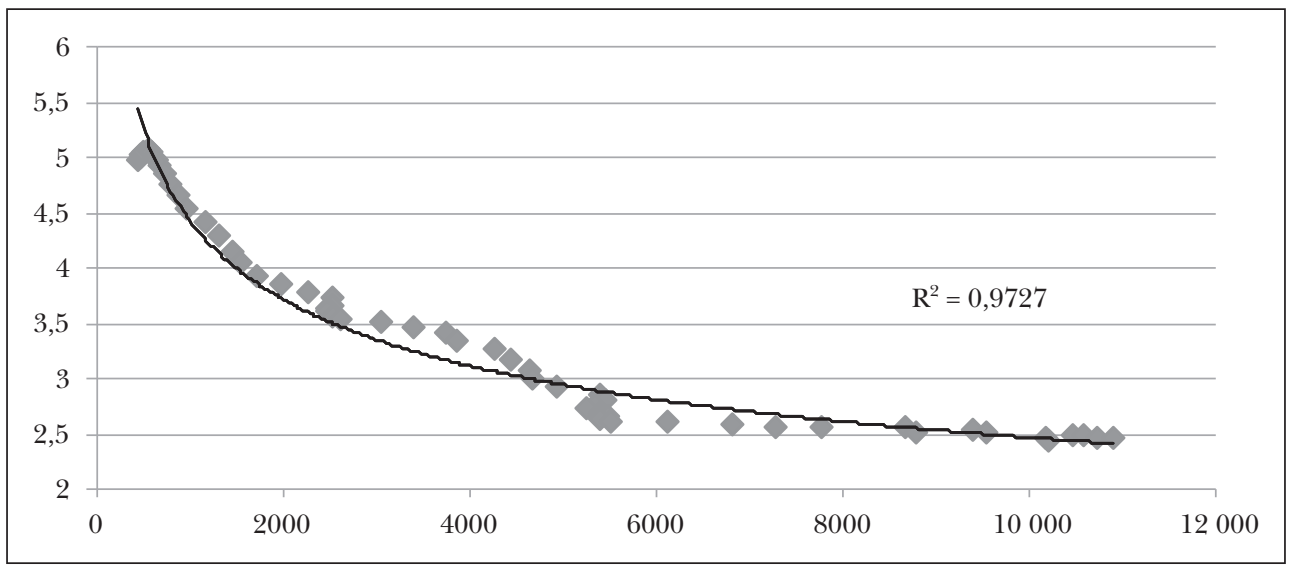

Forrás: Saját számítás a Világbank adatbázisa alapján 
Ez az ábra egy negatív hatványos összefüggésre mutat rá, amely hipotetikus függvényre majdnem teljes egészében illeszkedik a való adatsor $\left(R^{2}=0,9727\right.$, ez rendkívül erôteljes kapcsolat egy félig társadalmi-gazdasági elemzésben). A korrelációs kapcsolat is erôs, annak mértéke (Pearson-féle együttható) -0,897, úgy, hogy 1\%-os értéken is szignifikáns a kapcsolat az SPSS szerint. A 2. ábra alapján tehát mindenféle hezitálás nélkül ki lehet jelenteni, hogy a világ utóbbi évtizedeiben lejátszódó dinamikus életszínvonal-emelkedés negatívan befolyásolta a termékenységi ráta alakulását. A túlnépesedési tendencia még folyamatban van, de egyre közelebb kerül a globális termékenység is a 2-es értékhez. Az ábra tanúsága alapján azonban egyre kisebb mértékben csökken a termékenység, nem közelíti meg a visszaesés az idôszak közepén jellemzó erôteljes visszaesést. Másik fontos közvetett megállapításként arra mutatnék rá, hogy (bár nem közvetlenül erre a korszakra vonatkoztatják, legalábbis a nyugati világ esetében) az úgynevezett népességrobbanás kifejezés helyett szerencsésebb lenne az elmúlt évtizedeket a „gazdaságrobbanás” kifejezéssel illetni, hiszen 56 év alatt hússzorosára nôtt az átlagos életszínvonal úgy, hogy ez az értéket már a népességnövekedéssel korrigálták is.

\section{A TERMÉKENYSÉGI RÁTA ÉS GAZDASÁGI MEGHATÁROZÓI KÖZÖTTI KAPCSOLAT AZ EURÓPAi UNió 28 TAgÁllamábAN}

A globális folyamatokra tekintve megállapíthattuk, hogy összességében negatív kapcsolat mutatkozik az életszínvonal és a termékenységi ráta között. Az eróteljesebb negatív hatás az idôsort vizsgálva mutatkozott meg, vagyis a gazdasági fejlődési színvonal emelkedésével egyértelmúen együtt járt a termékenységi ráta visszaesése. A dinamikus megközelítés mellett azonban a statikus modell, az egy adott évre vonatkoztatott elemzés is hasonló irányú, kevésbé erôteljes kapcsolatot mutatott. Mindkét esetben szignifikánsnak minôsültek az összefüggések. Mindezek fényében inkább nevezhetô meglepónek azon modell eredménye, amikor már csak az Európai Unió jelenlegi 28 tagállamára szúkítettem a megfigyelési egységek körét.

Ebben a fejezetben egy olyan elemzés eredményei láthatóak, amelyben 19 gazdasági érintettségú változó és a termékenységi ráta közötti korrelációs kapcsolatot vizsgáltam. A változók kiválasztásakor arra törekedtem, hogy magas mérési szintúek legyenek, és jóléti, stabilitási, szociológiai, területi megközelítési (regionális gazdasági) ismérveket is be tudjak építeni. A bevont változók köre a következô: GDP/fó, városi népesség aránya, foglalkoztatási ráta, GINI-index, K+F-kiadások az exporton belül GDP-hez viszonyított aránya, ledolgozott heti munkaórák száma, metropolita térségekben lakó népesség aránya, munkanélküliségi ráta, internetfelhasználók aránya a népességen belül, CPI (korrupciós percepciós index, korrupcióérzékelési index), Bertelsmann Fenntarthatósági Kormányzás Index, Happy Planet Index, hazai hitelarány GPD-hez mért része, végsố fogyasztási kiadások aránya a GDP-hez viszonyítva, háztartási fogyasztás a GDP-hez mérve, hadászati kiadások a GDP-hez mérve, banki nem teljesítô hitelarány, állami nettó szociális transzferek aránya a GDP-hez mérve. 
Pintér Tibor: A természetes termékenységi ráta gazdasági meghatározói...

A korrelációs együtthatókat bemutató 1. táblázatban már nem az összes változó kapcsolata szerepel, csak a szignifikánsnak minősülő korrelációs együtthatókat tartalmazza. Ennek ellenére a nem szignifikáns változók irányára is kitérek a magyarázatban.

1. táblázat: A termékenységi ráta és azon gazdasági változók közötti kapcsolat korrelációs koefficiensei, amelyek szignifikánsnak minősülnek (szinte minden esetben 2016-os adatok)

\begin{tabular}{l|c}
\hline Bevont gazdasági változó & Termékenysági rátával való korreláció \\
\hline GDP/fố & $0,395^{*}$ \\
\hline Foglalkoztatási ráta & $0,544^{* *}$ \\
\hline K+F-kiadások, 2014 & $0,455^{*}$ \\
\hline Heti ledolgozott munkaóra & $-0,442^{*}$ \\
\hline Munkanélküliségi ráta & $-0,394^{*}$ \\
\hline Internetfelhasználók aránya & $0,479 * *$ \\
\hline CPI-korrupció & $0,548^{* *}$ \\
\hline Bertelsmann Sust. Ind. & $0,398^{*}$ \\
\hline Banki nem teljesítố hitelarány & $-0,438^{*}$ \\
\hline
\end{tabular}

Forrás: Saját számitás a Világbank hivatalos adatai alapján

A táblázat és egyéb kiegészítô információk alapján bizonyos megállapításokat tehetünk a termékenységi rátát és annak gazdasági meghatározó tényezőit illetôen. A táblázatban a Pearson-féle korrelációs együtthatók láthatóak, amelyek a páronkénti kapcsolat szorosságát és irányát jelzik. Az egy csillag azt jelenti, hogy a kétoldalú (two-tailed) szignifikancia értéke 5 százalékon belüli intervallumban mutatott érvényességet, a két csillag esetében ez 1 százalékot jelent, vagyis ott még erôsebb a validitás. Egyik érték sem kiemelkedôen magas, nem lehet kijelenteni, hogy erôteljes gazdasági determinációja lenne a termékenységi rátának.

Abszolút értékben a CPI, vagyis a korrupciós érzékelési index, valamint a foglalkoztatási ráta mutatja a legnagyobb számértéket. Mindkettô pozitív előjeles kapcsolatot mutat. Ismerve a mutatók képzési módszerét, azt a következtetést vonhatjuk le, hogy minél kevésbé korrupt egy társadalom (hiszen akkor nô a mutató értéke, ha nem érzékelhetố vagy kevésbé érzékelhetô a korrupció), annál erôteljesebb pozitív irányú elmozdulás várható a termékenységben is. A korrupciótól való mentesség mellett (amelynek a mérése természetesen túlzottan normatív tartalmú lehet) meghatározónak bizonyul (fenntartva azt a megállapítást, hogy egyik együttható sem kifejezetten magas) az ország foglalkoztatási rátája is. Ezt úgy értelmezhetjük, hogy az aktív munkaerópiaci részvétel egyfajta egzisztenciális alapként funkcionál a gyermekvállalási hajlandóságot támogatva. Kevésbé erôteljes, de pozitív kapcsolatot mutat az internetfelhasználók magasabb aránya, valamint az exporton belül a K+F-igényes termékek erôteljesebb jelenléte. Mindez arra mutat rá, hogy a tudományos fejlettségi szint és 
a képzettség áttételesen javíthatja egy magas életszínvonalú ország esetében a termékenységi kilátásokat. Globálisan pontosan az ellenkezôjét láthatjuk ezeknél a változóknál, fejlett országokra szúkítve az elemzést viszont megfordul a kapcsolat irányultsága.

Az egy fớre jutó GDP, valamint a Bertelsmann Intézet Fenntartható Kormányzás Indexe hasonló erôsségú pozitív kapcsolatra mutat rá. Fóleg az elsô eredmény lehet meglepô, hiszen globális kitekintésben az egy fớre eső GDP adott évben és idôsorosan is egyértelmúen negatív kapcsolatban volt a termékenységgel. Ebben az országkörben, az Európai Unió 28 tagállamában viszont egy enyhe pozitív kapcsolat mutatkozik a termékenység és az életszínvonal között. Ilyen módon nem tekinthetô feleslegesnek egy EU-tag esetében a gyermekvállalás anyagi ösztönzôkkel való támogatása, legalábbis a termékenységi ráta 1 és 2 közötti tartományában. Ez az eredmény ellentmond az elôzetes kutatói várakozásaimnak, azt feltételeztem, hogy az EU-n belül is fennmarad a negatív irányultság.

A szignifikáns összefüggések közül mindössze három változó mutat negatív kapcsolatot a termékenységi rátával. Ez a három változó a ledolgozott munkaórák száma, a nem teljesítô banki hitelek aránya a teljes hitelállományhoz képest, valamint legutolsóként a munkanélküliségi ráta. Minél több idôt töltenek tehát az emberek a munkahelyükön, annál alacsonyabb termékenységi rátával számolhatunk. Ez magától értetôdônek tûnik, ellenben a foglalkoztatásnál pozitív kapcsolatot láttunk. Éppen ezért fontos felhívni az olvasó figyelmét, hogy önmagában nem a munkavégzés, hanem a nem jól szervezett, nem jól beosztott munkavégzés és munkaidô jelentheti gátját a gyermekvállalásnak. Ebból következôen érdemes lenne a rugalmas és a hatékony munkavégzés célkitúzését immanens elemmé tenni a jogalkotási és vállalatvezetési körökben is. Ezzel még inkább fel lehetne oldani a munka és család közötti ellentétet.

Annak ellenére, hogy a nem teljesítô hitelek állománya abszolút értékben 0,5 alatti értéket mutat, ami nem kifejezetten karakteres összefüggés, mégis ki kell térni erre a változóra is a magyarázó bekezdések között. Ebból következtethetô, hogy a gyermekvállalási hajlandóságot visszaszorítja az olyan hitelek állománya a magánszférában, amelyek esetében nem biztosított a kellô anyagi fedezet. Ez a kapcsolat hasonlóságokat mutat a már eddig kifejtettekkel. Az egzisztenciális biztonság ugyanis nemcsak akkor kerülhet veszélybe, ha nincs kiszámítható állása egy adott embernek, hanem abban az esetben is, amikor a bevételek nem elegendóek a törlesztési részletek finanszírozására. Éppen ezért megfontolandó, hogy egy országban koncepcionálisan kössék össze a termékenység támogatását a pénzügyi kultúra emelésével és a stabil pénzügyi rendszer biztosításával. Mindezt csak megerôsítik azok a mostani vizsgálatba nem bevont, de általam elvégzett elemzések, amelyek bizonyos országokkal összefüggő kockázati tényezôk (például World Economic Forum EOS kockázati értéke) esetében azt mutatták meg, hogy egy ország mentesítése a kockázati tényezôktôl pozitívan befolyásolják a termékenységi pálya alakulását.

A nem szignifikáns kapcsolatok esetében a következố tendenciák érvényesültek. A városi lakosság aránya, valamint a metropolita (nagyvárosi) térségek lakosságának aránya igen enyhe pozitív kapcsolatban van a termékenységgel. A GINI-index gyenge negatív kapcsolatot mutat a termékenységgel, vagyis az egyenlótlenebb jövedelemeloszlás inkább visszaveti a gyermekvállalást. A Boldog Bolygó Index (Happy Planet 
Pintér Tibor: A természetes termékenységi ráta gazdasági meghatározói...

Index) semleges értéket vesz fel $(0,052)$, a hitelarány, a háztartási és végsố fogyasztás, valamint a hadászati kiadások egyaránt negatívan befolyásolják a termékenységet, ahogyan az állami nettó szociális transzferek aránya is a GDP-hez mérve. Ilyen módon tehát a szociális ellátórendszer kiterjedtsége önmagában nem kifejezetten fontos tényezô, a fogyasztás pedig inkább negatív hatást mutat. Amennyiben a családtámogatási kiadásokat arányosítjuk a GDP-hez (erre csak OECD-adataink vannak, OECD-országokra vonatkoztatva, tehát megváltozik az alapminta), akkor csak egy 0,06-os, rendkívül gyenge pozitív korrelációs együtthatót kapunk.

\section{MAgYARORSZÁG TERMÉKENYSÉGi RÁTÁJÁNAK ALAKULÁSA, ANNAK GAZDASÁGI HÁTTERE}

Magyarországon a jelenlegi kormányzat nagy hangsúlyt helyez a demográfiai kérdésekre. Ennek a politikai intézkedéssorozatnak egy újabb állomását jelenti a 2019 februárjában bejelentett hétpontos családvédelmi akcióterv. A tanulmányban bemutatott termékenységi értékek is igazolják, hogy általánosságban az Európai Unió tagállamaiban, így Magyarországon is inkább a túlzottan alacsony termékenységi ráta a jellemzô, ez a jelenség önmagában a társadalmi-gazdasági rendszer fenntarthatóságát veszélyezteti. Arra vonatkozóan különféle elképzelések léteznek, hogy ezt a válságot külsố erôforrásokra alapozva vagy csak a belsố lakosság termékenységi értékeinek növelésével lehet-e kezelni, és egyáltalán gazdaságpolitikai intézkedések jelenhetik-e a kulcstényezôt. Ezeknek a nem elhanyagolható, de nem kifejezetten csak gazdasági kérdéseknek az összetett megválaszolásával nem foglalkozik e tanulmány.

A magyar termékenységi ráta pályájának alakulását vizsgálva azt kell megelólegeznünk, hogy hazánk sem tudta függetleníteni magát attól az európai trendtôl, hogy az életszínvonal emelkedésével trendszerúen visszaesett a termékenységi ráta. Ez a kijelentés nem olyan egyszerú, mint amilyennek elsốre tûnik, hiszen csak abban az esetben igaz, amennyiben a nemzetközileg elfogadott SNA-mutatókban fejezzük ki az életszínvonalat. Ebben a tanulmányban jóléti színvonal kifejezésére az egy fớre jutó GDP-t használjuk, kifejezetten annak a vásárlóerô-paritáson vett értékét. Adódnak persze kérdések, amelyeket most nyitva hagyunk. Néhány ezek közül: Milyen kapcsolat mutatkozna a két kategória között, amennyiben reálbéreket vennénk figyelembe? Milyen kapcsolat mutatkozna akkor, amikor megkülönböztetnénk az eladósodásból, külföldi tôkebevonásból fedezett növekedést a belsố erőforrásokra támaszkodó növekedéstôl? Az elmúlt évek tapasztalatai azt mutatják, hogy a társadalom sokkal inkább ezekre, a mindennapokban érezhetô gazdasági kategóriákra alapozza döntéseit, így a gyermekvállalást is - amennyiben ennek a kérdésnek az anyagi hátterét keressük.

A 3. ábra Magyarország termékenységi rátájának alakulását mutatja be 1942-tôl kezdődôen. A KSH online adatbázisa a kezdeti idôszakra hozzávetôlegesen évtizedes bontásban közli ezeket az adatokat, majd 2001-tôl éves bontásban is. Jól látható, hogy egy bôven 2 feletti értékrôl csökkent le a mutató már 1970-re éppen 2 alá, az eddigi mélypont pedig 2011-ben mutatkozott, 1,23-as értékkel, ahonnan 2017-re 1,49-ig nôtt a termékenységi ráta. 
3. ábra: A termékenységi ráta Magyarországon (1941-2017)

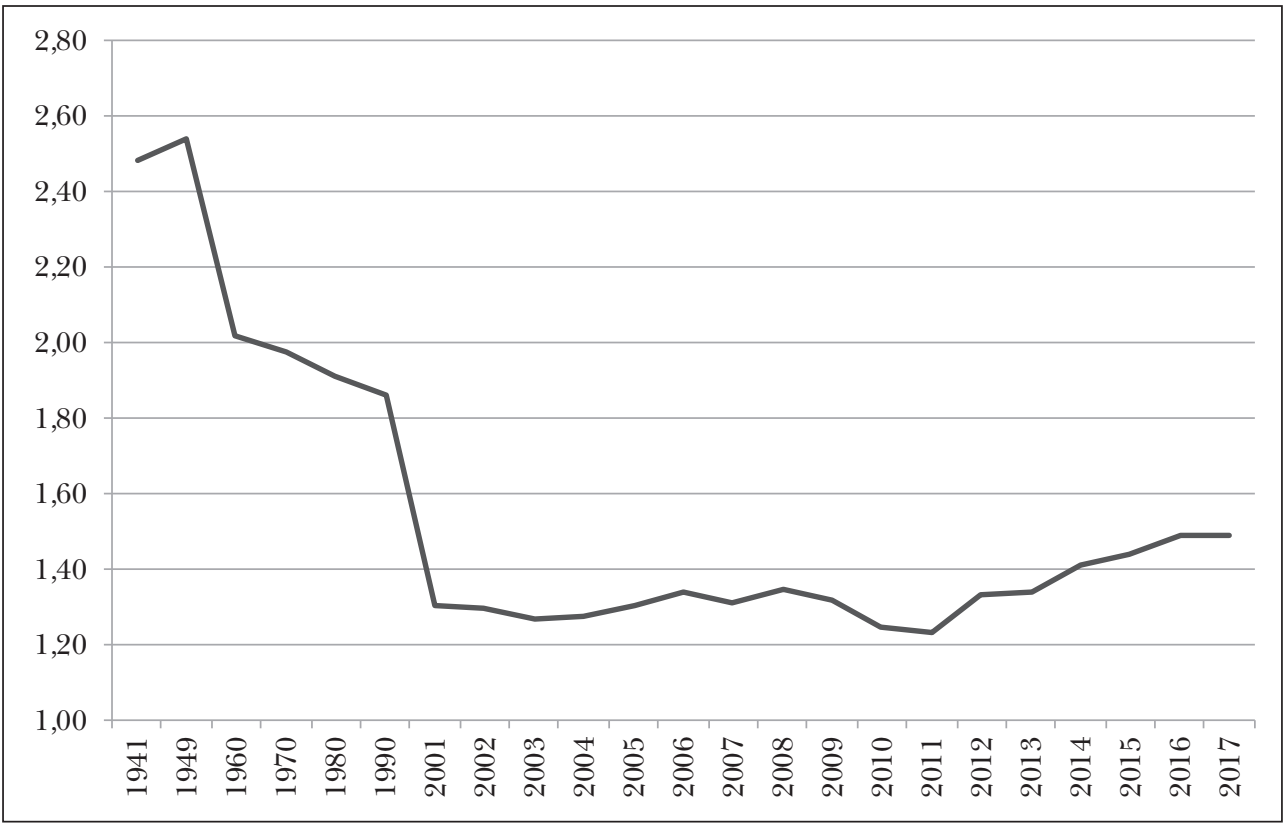

Forrás: $\mathrm{KSH}$

A 3. ábra arra a társadalom- és gazdaságtörténeti átmenetre utal, hogy hazánk is azon országok körébe tartozik, ahol a társadalom értékrendjében elótérbe került az életszínvonal, amelyért a demográfiai fenntarthatatlanság sem túlzottan magas ár. A fentebb említett határozott politikai akarat, valamint az a korábbi megállapítás, miszerint a magasabb életszínvonalú országok esetében enyhe pozitív kapcsolat mutatható ki az egy fớre esố GDP és a termékenység között, valamelyest árnyalja a magyar helyzetet is.

Tomka Béla 2016-ban kiadott könyvében leírja, hogy a magyar társadalom és politika célkeresztjében jelentôs szerepet játszott Ausztria mint referenciaország. Éppen ezért érdemesnek tartottam nem kifejezetten az EU-átlaghoz (bár többé-kevésbé azonos tendenciát láthatnánk), hanem az osztrák életszínvonalhoz viszonyítani a magyart. A 4. ábra azt mutatja be, hogy a rendszerváltást követően hogyan alakult a magyar egy foóre esố vásárlóerô-paritáson vett GDP osztrákhoz viszonyított arányának pályája, valamint a termékenységi ráta. Ez a pálya elvileg fontos viszonyítási pontot képezett a magyar társadalom és a magyar politikai elit számára is. Az ábra két függóleges tengellyel rendelkezik. A bal oldali tengely méri a magyar egy fốre esô GDP alakulását az osztrák százalékában, míg a jobb oldali a termékenységi ráta alakulását. A vizsgált időszak 1991 és 2017 közé esik. Azért csak ezekre az évekre koncentráltam, mert a Világbank a volt államszocialista országokra csak 1990 után publikált hivatalos SNA-mutatós statisztikákat. 
Pintér Tibor: A természetes termékenységi ráta gazdasági meghatározói...

4. ábra: A termékenységi ráta és a magyar életszinvonal (az osztrák életszinvonal százalékában kifejezett) alakulása Magyarországon (1991-2017)

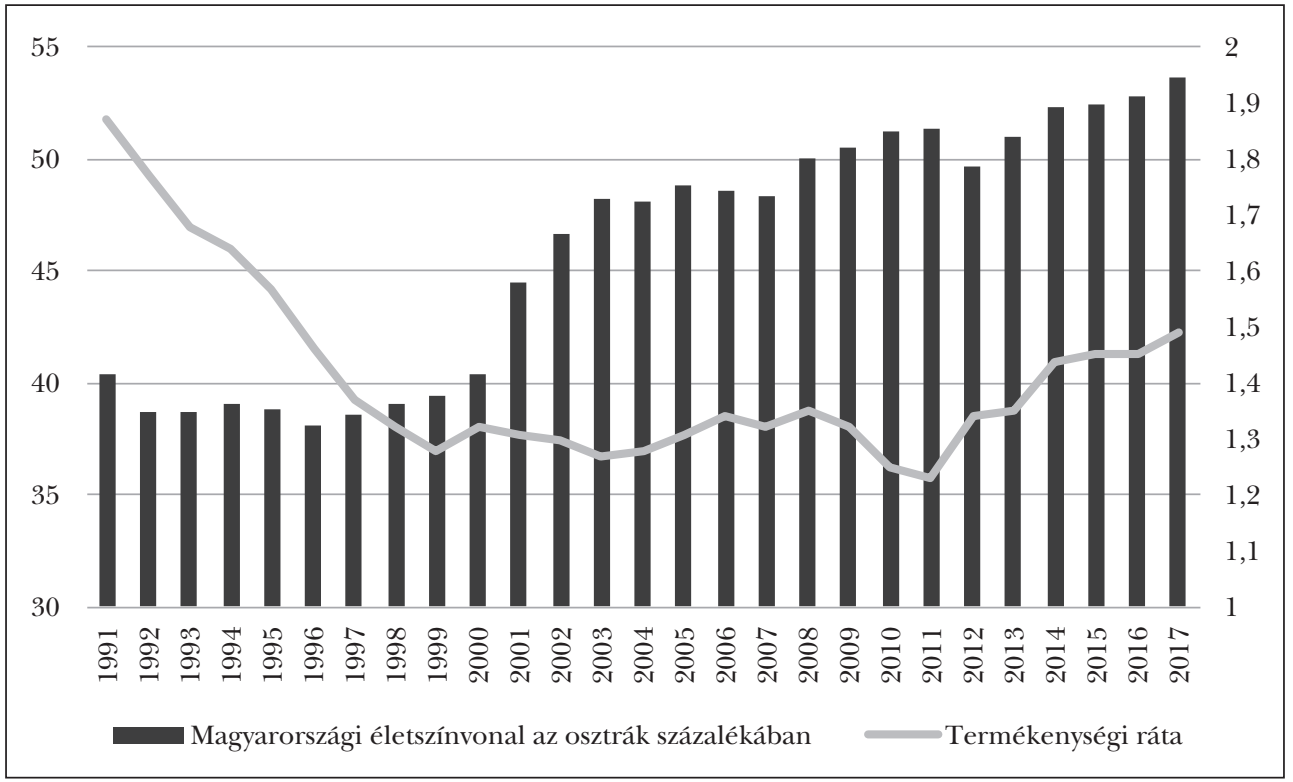

Forrás: Saját szerkesztés a KSH és a Világbank adatai alapján

Mint látható, nagyságrendileg sokkal kedvezóbb helyzetben van életszínvonal tekintetében Magyarország Ausztriához viszonyítva, mint amilyen helyzetben a kilencvenes évek elején volt. A felzárkózás nem feltétlenül érezhetô ekkorának a hétköznapokban, ennek okairól már a fejezet elején is írtam, mindezt azzal is kiegészíteném, hogy jelentős területi különbségek is mutatkoznak a felzárkózásban - követve a többi régiós ország fejlődési mintáját. Arra azonban mindenképpen rá kell mutatnunk, hogy a termékenységi ráta 2011 utáni növekedése egy életszínvonalbeli felzárkózással is öszszefonódott, vagyis inkább jótékony hatást gyakorolt a dinamizálódó gazdasági növekedés a demográfiai folyamatokra, kérdéses azonban a termékenységi mutató további növelése a 2 közeli tartományba.

A termékenységi ráta és az életszínvonal közötti nem egyértelmú kapcsolatra mutat rá az 5. ábra is. Idôsoros elemzési eljárást alkalmazva feltehetjük a kérdést - ahogyan ezt a globális szinten már megtettük -, hogyan is alakul az egy főre esô GDP és a termékenységi ráta Magyarországon 1990 után?

A regressziós függvény úgynevezett polinomiális alakot ölt, a pontfelhô közepesen erôsen illeszkedik erre a hipotetikus regressziós egyenesre. Az ebból az ábrából levonható következtetés sem üt el az előzốektôl, vagyis a vizsgált időszak elején csökken a termékenységi ráta a GDP-növekedés hatására, majd egy bizonyos ponton túl növekszik. Amennyiben túlzottan elméleti síkon maradnánk, akkor azt állapíthatnánk meg, hogy a magyar gazdaság egy bizonyos egy fốre esô GDP-értéket követôen elérte azt a 
5. ábra: A termékenységi ráta és az egy fôre esố GDP közötti regressziós függvény képe 1990 után

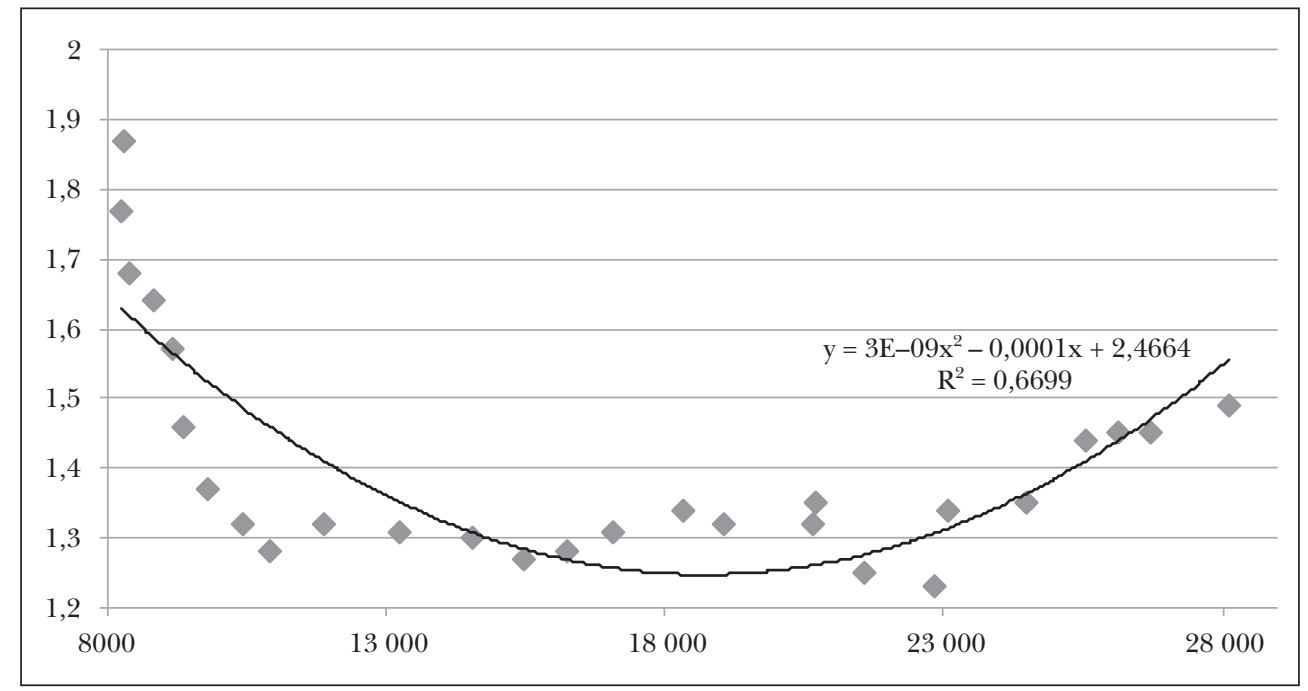

Forrás: Saját szerkesztés a KSH és a Világbank adatai alapján

tartományt, ahol már egy gyenge pozitív kapcsolat mutatkozik a gazdasági értelemben vett életszínvonal növekedése és a termékenységi ráta között. Amennyiben jobban elrugaszkodunk a modell jelentésétôl, akkor persze utalnunk kell arra, hogy a rendszerváltás utáni átalakulások, a megváltozott társadalmi értékrend szintén komoly hatást gyakorolhatott a demográfiai pályára, majd az összegyújtött kollektív tapasztalatok az új rendszerrôl, valamint a megváltozott kormányzati politika kedvezóbb irányba terelhették a demográfiai pályát.

Erre utalnak azok a kutatási eredmények is, amelyeket hazai egyetemisták körében végeztek el Sági és szerzótársai (Sági et al., 2017). A több mint ezer megkérdezett egyetemista egyértelmúen pozitívan nyilatkozott a hazai, tudatos, anyagi támogatási eszközöket is alkalmazó családtámogatási rendszerról. A megkérdezettek nagy többsége pozitív, gyermekvállalást serkentó tényezónek tartotta a családoknak nyújtott fiskális politikai ösztönzôket. Fontos azt is kiemelni, hogy egy másik kutatás arra is rámutatott: a közpénzügyi hosszabb idôtávon vett fenntarthatóság szempontjából is kiállja az idôk próbáját a magyar gazdaságpolitikai eszköztárban alkalmazott család- és otthonteremtési kedvezmény (Tatay et al., 2019).

A 2. táblázat nem a termékenységi rátának, hanem az ezer fớre vetített élve születéseknek az alakulását mutatja be a 7 NUTS2-es szintú magyarországi régióra vetítve. Már az alapadatokból is látható, hogy adott években más-más értékeket vesz fel az élve születések száma, míg a régiók gazdasági sorrendje inkább stabil képet mutat. Amenynyiben erre a hét régióra kiszámoljuk a Pearson-féle korrelációs mutatót, akkor rendre a következố adatokat kapjuk a vizsgált években: $-0,4587 ; 0,1439 ; 0,5434 ;-0,1372$; $-0,283$. Jól láthatóan nemcsak az értékek változnak, hanem az elójel is. 2001-ben és 
Pintér Tibor: A természetes termékenységi ráta gazdasági meghatározói...

2. táblázat: Az 1000 lakosra jutó élve születések és az országos átlagos GDP/fó adathoz képest vett eltérés Magyarország NUTS-2-es régióiban

\begin{tabular}{|c|c|c|c|c|c|c|c|c|c|c|}
\hline \multirow[b]{2}{*}{ Régió } & \multicolumn{2}{|c|}{2001} & \multicolumn{2}{|c|}{2005} & \multicolumn{2}{|c|}{2010} & \multicolumn{2}{|c|}{2015} & \multicolumn{2}{|c|}{2017} \\
\hline & $\begin{array}{c}\text { GDP } \\
\text { átlag } \\
\%\end{array}$ & $\begin{array}{c}\text { Élve- } \\
\text { születés } \\
1000 \\
\text { lakosra }\end{array}$ & $\begin{array}{c}\text { GDP } \\
\text { átlag } \\
\%\end{array}$ & $\begin{array}{c}\text { Élve- } \\
\text { születés } \\
1000 \\
\text { lakosra }\end{array}$ & $\begin{array}{c}\text { GDP } \\
\text { átlag } \\
\%\end{array}$ & $\begin{array}{c}\text { Élve- } \\
\text { születés } \\
1000 \\
\text { lakosra }\end{array}$ & $\begin{array}{c}\text { GDP } \\
\text { átlag } \\
\%\end{array}$ & $\begin{array}{c}\text { Élve- } \\
\text { születés } \\
1000 \\
\text { lakosra }\end{array}$ & $\begin{array}{c}\text { GDP } \\
\text { átlag } \\
\%\end{array}$ & $\begin{array}{c}\text { Élve- } \\
\text { születés } \\
1000 \\
\text { lakosra }\end{array}$ \\
\hline $\begin{array}{l}\text { Kö- } \\
\text { zép-M. }\end{array}$ & 157,7 & 9,1 & 162,4 & 9,9 & 165,8 & 9,8 & 153,5 & 9,4 & 152,9 & 9,2 \\
\hline $\begin{array}{l}\text { Kö- } \\
\text { zép-D. }\end{array}$ & 92,5 & 9,1 & 94 & 9,3 & 86,6 & 8,7 & 93,1 & 9,1 & 92,3 & 9 \\
\hline $\begin{array}{l}\text { Nyu- } \\
\text { gat-D. }\end{array}$ & 102,3 & 8,7 & 98,9 & 9 & 99 & 8,2 & 107,9 & 8,3 & 105,6 & 8,5 \\
\hline Dél-D. & 73,2 & 9,1 & 69 & 9,1 & 67,5 & 8,2 & 64,9 & 8,5 & 66,3 & 8,5 \\
\hline Észak-M. & 65,7 & 10,1 & 66,2 & 9,8 & 60,1 & 9,2 & 66,3 & 9,9 & 67,4 & 10,4 \\
\hline Észak-A. & 68 & 10,8 & 64,4 & 10,3 & 63,4 & 9,1 & 63,7 & 10,1 & 63,5 & 10,2 \\
\hline Dél-A. & 73,8 & 9 & 68,9 & 9 & 64,8 & 8 & 71,7 & 8,6 & 71,2 & 8,9 \\
\hline
\end{tabular}

Forrás: Saját szerkesztés a KSH adatai alapján

2015-ben, 2017-ben negatív kapcsolat mutatkozik az életszínvonal és a születések között, 2005-ben és 2010 viszont pozitív a kapcsolat. Ezek értelmében bizonyos években inkább ott magasabb a születések száma, ahol magasabbak a jóléti mutatók is, bizonyos években viszont oda koncentrálódik a nagyobb születési szám, ahol kevésbé magas az életszínvonal. Ennél megbízhatóbb eredményekre jutnánk, amennyiben mélyebb területi szinten, akár csak megyei szinten vizsgálódnánk, de így is látható, hogy a születések a jelenben sem feltétlenül ott koncentrálódnak, ahol a gazdasági mutatók azt indokolnák.

A termékenységi ráta és annak gazdasági háttere közötti kapcsolatról az alábbi öszszegzô és kitekintố gondolatokat tehetjük meg az adatok, a szakirodalmi összegzés és a mindennapi tapasztalatok alapján. Magyarország globális és európai perspektívából tekintve is abba az országkörbe tartozik, ahol kimutatható pozitív kapcsolat a gazdasági értelemben vett életszínvonal és a termékenységi ráta között, ezért érdemes a politikának a gyermekvállalás anyagi oldalával is foglalkoznia. A termékenységi ráta utóbbi években tapasztalt javulása is megerôsíti az utóbbi megállapítást. Modellszámítások alapján pedig állampénzügyi értelemben is fenntartható a mai magyar családtámogatási modell. A globális értelemben vett negatív kapcsolat, valamint a belsố területi folyamatok viszont arra is rámutatnak, hogy a gazdaságon túli tényezókben is kell keresni a hazai, még alacsonynak minôsülô termékenységi adatokat. Minden bizonnyal a túlzott individualizációval is összefüggésbe hozható emberkoncepcióval szembeni kulturális és politikai szerepvállalás is segíthet a kedvezóbb tendencia elérésében (Lentner et al., 2017). 


\section{Polgári Szemle $\cdot$ 15. évfolyam 1-3. szám}

\section{ÖsSZEGZÉS，KÖVETKEZTETÉSEK}

Jelen tanulmánynak az volt a legfontosabb célkitúzése, hogy tisztázza: van-e érdemleges kapcsolat a gazdasági értelemben vett fejlettségi szint és a termékenységi ráta között. A kutatási eredmények alapján levonható következtetések ellentmondásos kapcsolatra mutatnak rá. Egyrészt kijelenthetjük, hogy a világon jellemzóen azokban az országokban magas a termékenységi ráta, ahol az életszínvonal alacsony, legalábbis átlag alatti. Ezt a negatív kapcsolatot a két változó között csak megerôsíti a termékenységi rátának az 1960 utáni idôszakban tapasztalható erôteljes csökkenése, amellyel párhuzamosan viszont dinamikusan növekedett az egy fốre jutó átlagos GDP. Globális tekintetben tehát az a jellemzô, hogy az életszínvonal növekedése visszaveti a termékenységet. Nem tudhatjuk természetesen, hogy a termékenységi ráta a továbbiakban is ilyen mértékben fog-e csökkenni, lehetséges, hogy a 2-es értékhez közelítve lassuló tendenciát láthatunk majd, az eddigi pályát vizsgálva legalábbis erre következtethetünk.

Meglepően más képet mutat viszont az életszínvonal és a termékenységi ráta kapcsolata, amikor csak az Európai Unió tagországait vesszük szemügyre. Ebben az országcsoportban pozitív irányúvá fordul át a kapcsolat, hozzá kell tenni, hogy nem kifejezetten eróteljes a kimutatható korreláció, de pozitív irányú. A fejlett országoknak ebben a csoportjában szinte kivétel nélkül problémát okoz a biológiai szintú újrateremtődés, vagyis pozitív migrációs egyenleg nélkül csökken a népességük. Ilyen feltételek között pozitív kapcsolatot mutatnak a bevont adatok a gazdasági fejlettség, a korrupciótól való mentesség, a foglalkoztatás, valamint az újdonságok iránti társadalmi-gazdasági nyitottság tekintetében - a termékenységi rátával összefüggésben. Ennek értelmében tehát megalapozottnak túnhet egy ország termékenységi rátájának dinamikáját ezekkel a gazdasági ösztönzőkkel is támogatni. Ebből nem következik az, hogy ne lennének ennél erôteljesebb eszközök e cél elérése szempontjából, de mutatkozik egyfajta mozgástér a termékenységi ráta gazdasági megalapozottságú támogatására. Úgy túnik, hogy a munkaerôpiaci kiszámíthatóság és a kiadásokat fedezni képes háztartási bevételek serkenteni tudják a termékenységet. Azonban arra is fel kell hívni a figyelmet, hogy nagyobb idôtáv vizsgálata itt is indokolt lehetne, valamint az is kiemelendô, hogy az EU-28-tagállamok általános demográfiai összképén ez a modell sem változtat. Minden egyes tagállamban jelentôs problémát jelent az alacsony termékenység - ez a tény egyéb fejlett térségekben is jelentkezik, Észak-Amerikától Délkelet-Ázsiáig. Azt is fel lehet természetesen vetni, hogy a fejlett világ lakossága túlértékeli a gyermekvállalás gazdasági vonzatát, egészen egyszerúen anyagi értelemben túlbiztosítja azt. Minden bizonnyal igaz lehet ez a sejtés, ennek ellenére is úgy túnik, hogy ezen az életszínvonalon igenis van anyagi vonzata is a gyermekvállalásnak. Sót, nemcsak anyagi igények, de kockázatcsökkentési, intézményrendszer-stabilitási és jólétirendszer-fenntartási igények is felmerülhetnek a termékenység támogatása (de nem feltétlenül a klasszikus eszközökkel, ahogyan arra az OECD-országok értéke rámutat) kapcsán ezekben az országokban, köztük természetesen Magyarországon is.

A kérdéskör összetettsége természetesen a fentinél komplexebb megközelítést igényelne. Olyan szociológiai, pszichológiai paramétereket is be kellene emelni a ké- 


\section{Pintér Tibor: A természetes termékenységi ráta gazdasági meghatározói...}

sôbbi vizsgálatokba, amelyek például az egyén élethosszán, izolált érdekrendszerén, hasznosságérzetén túlmutató megfontolásokat is képesek lennének megragadni. John D. Mueller nyomán például a transzcendencia, vallásosság igen fontos tényezô lehet a termékenység támogatásában (a heti templomba járás gyakorisága mutatja a legerôsebb pozitív kapcsolatot a termékenységgel az amerikai szövetségi államokban), valószínúsíthetốn idesorolható egy ország, magasabb minôségként egy nemzet, pozitív és korszerú énképének, identitásának megléte, megerôsítése is.

\section{FELHASZNÁLT IRODALOM}

Barro, Roberto (2013): Health and Economic Growth. Annals of Economics and Finance, Vol. 14, No. 2.

Becker, Gary (1960): An Economic Analysis of Fertility. In: Roberts, G. B (ed.): Demographic and Economic Change in Developed Countries. NBER, Boston, 209-240.

Berde Éva - Kovács Eszter (2016): A svéd és a magyar termékenységi arányszám összehasonlítása. Közgazdasági Szemle, 63. évf., 12. sz., 1348-1374., https://doi.org/10.18414/ksz.2016.12.1348.

Berde Éva - Kuncz Izabella (2017): Az egy fốre jutó GDP lehetséges pályái - szimuláció egy demográfiai alapú növekedési modellel. Hitelintézeti Szemle, 16. évf., 4. sz., 36-57., https://doi.org/10.25201/hsz. 16.4.3657.

Berde Éva - Németh Petra (2016): A magyarországi termékenység paritásonkénti alakulása 1970 és 2011 között. Köz-gazdaság, 11. évf., 2. sz., 129-148.

Dusek Tamás - Kotosz Balázs (2016): Területi statisztika. Akadémiai Kiadó, Budapest, https://doi. org/10.1556/9789634540014.

Farkas Tamás (2017): Lengyelország, Csehország és Szlovákia családtámogatási rendszereinek összehasonlítása. Demográfia, 60. évf., 4. sz., 333-376., https://doi.org/10.21543/dem.60.4.3.

Giday, András - Szegó, Szilvia (2018): Towards the „Child-to-Parent” Based Pension Allowance („C2P”). Polgári Szemle/Civic Review, Vol. 14, Special Issue, 302-319, https://doi.org/10.24307/psz.2018.0420.

Hussain, Shahzad - Malik, Shahnawaz - Hayat, Muhammad K. (2009): Demographic Transition and Economic Growth in Pakistan. European Journal of Scientific Research, Vol. 31, No. 3, 491-499.

Jones, Larry E. - Schoonbroodt, Alice (2010): Fertility Theories: Can They Explain the Negative Fertility-Income Relationship? In: Shoven, John B. (ed.): Demography and the Economy. NBER, Boston, 43-100, https://doi.org/10.7208/chicago/9780226754758.003.0003.

Kucséber László Zoltán (2011): A munkanélküliség gazdasági és társadalmi következményei. In: Róbert Péter (szerk.): Magyarország társadalmi-gazdasági helyzete a 21. század elsó évtizedeiben. Széchenyi István Egyetem, Gyôr, 195-203.

Lentner Csaba - Novoszáth Péter - Sági Judit (2017): A magyar családpolitika és a születésszám alakulásának egyes kiemelt területei demográfiai, szociológiai és állampénzügyi vetületben, nemzetközi kitekintéssel. Pro Publico Bono - Magyar Közigazgatás, 5. évf., 4. sz., 106-133.

Malthus, Thomas (1998) [1798]: An Essay on the Principle of Population. J. Johnson, in St. Paul's Church-Yard, London, www.esp.org/books/malthus/population/malthus.pdf.

Mason, Andrew - Lee, Ronald - Lee, Sang-Hyop (2010): The Demographic Transition and Economic Growth in the Pacific Rim. In: Ito, Takatoshi - Rose, Andrew (eds.): The Economic Consequences of Demographic Change in East Asia. University of Chicago Press, Chicago, https://doi.org/10.7208/chicago/9780226386881.003.0002.

Molnár Tamás (2015): Empirikus területi kutatások és módszerek. Akadémiai Kiadó, Budapest.

Mueller, John D. (2010): Redeeming Economics. Rediscovering the Missing Element. ISI Books, Wilmington.

Prskawetz, Alexia - Lindh, Thomas (eds.) (2007): The Relationship Between Demographic Change and Economic Growth in the EU. Institut für Demographie Österreichische Akademie der Wissenschaften, Wien.

Sági Judit - Tatay Tibor - Lentner Csaba - Neumanné Virág Ildikó (2017): A család- és otthonteremtési adókedvezmények, illetve támogatások egyes hatásai. Pénzügyi Szemle, 62. évf., 2. sz., 173-189. 
Sági, Judit - Lentner, Csaba (2018): Certain Aspects of Family Policy Incentives for Childbearing - a Hungarian Study with an International Outlook. Sustainability, Vol. 10, No. 11, 1-16, https://doi.org/10.3390/ su10113976.

Sági, Judit - Lentner, Csaba - Tatay, Tibor (2018): Family Allowance Issues. Hungary in Comparison to Other Countries. Polgári Szemle/Civic Review, Vol. 14, Special Issues, 290-301, https://doi.org/10.24307/ psz.2018.0419.

Schultz, Theodore W. (1974): Fertility and Economic Values. In: Schultz, Theodore W. (ed.): Economics of the Family: Marriage, Children and Human Capital. NBER, Boston, 3-22.

Sobotka, Tomas - Skirbekk, Vegard - Philipov, Dimiter (2011): Economic Recession and Fertility in the Developed World. Population and Development Review, Vol. 37, No. 2, 267-306, https://doi.org/10.1111/ j.1728-4457.2011.00411.x.

Széll Krisztián (2010): Idôsödô társadalom és az oktatási rendszer. Statisztikai Szemle, 88. évf., 3. sz., 273-304.

Tatay Tibor - Sági Judit - Lentner Csaba (2019) : A családi otthonteremtési kedvezmény költségvetési terheinek előreszámítása, 2020-2040. Statisztikai Szemle, 97. évf., 2. sz., 192-212., https://doi.org/10.20311/ stat2019.2.hu192.

Tomka Béla (2016): Gazdasági növekedés, fogyasztás és életminốség. Magyarország nemzetközi összehasonlitásban az elsố világháborútól napjainkig. Akadémiai Kiadó, Budapest.

Varga Beatrix (2005): A magyarországi termékenységi mozgalom területi különbségei. Gazdaságtudományi Közlemények, 4. évf., 1. sz., 52-63.

Yang, Hsiu-ling (2000): Education, Married Women's Participation Rate, Fertility and Economic Growth. Journal of Economic Development, Vol. 25, No. 2, 101-118.

Yang, Zining (2016): An Agent-Based Dynamic Model of Politics, Fertility and Economic Development. Journal of Systemics, Vol. 14, No. 1, 68-72. 